\title{
Corporate Governance, Participation and Microfinance Performance:
}

\author{
Empirical Evidence from Indonesia
}

\author{
Suhadak* \\ Department of Business Administration \\ Brawijaya University \\ Malang, Indonesia \\ *suhadak_fia@yahoo.co.id
}

\author{
Jung-Hua Hung \\ Department of Business Administration \\ National Central University \\ Taiwan \\ jhung@cc.ncu.edu.tw
}

\author{
Moh. Heru Budihantho \\ Student of Doctoral Program of Business Administration \\ Brawijaya University \\ Malang, Indonesia \\ moh.herubudihantho@gmail.com
}

\begin{abstract}
The objectives of this research is to investigate the effects on participation of corporate governance, corporate governance on financial performance and social performance, financial performance on social performance in MFI community empowerment programs. This is explanatory research with a quantitative method. The data were collected from $75 \mathrm{MFi}$. Data analysis used WarpPLS. Results of the study showed that corporate governance impact affect positively significant to participation, corporate governance affect negatively significant to the financial and social performance, participation affect negatively significant to the financial performance and social performance and financial performance positive significant effect on financial performance, this shows that there is no trade-off between financial sustainability and the social mission of MFi.
\end{abstract}

Keywords-corporate governance, partisipation, financial Performance and social performance

\section{INTRODUCTION}

The government of Indonesia has executed many programs to alleviate poverty due to the economic crisis in 1988, those programs were: PPK (Program Pengembangan Kecamatan/ Sub-District Development Program) Later, these two programs were extended as Independent Rural PNPM (Program Nasional Pemberdayaan Masyarakat/ National Program for Community Empowerment) as the perfected version of PPK. On of the programs prioritize managing the revolved fund for female groups, for the rural community [1]. Besides, the government also launched the program of Community Empowerment Rural Development (CERD) in 2001-2008. One of the component activities is the poverty alleviation program by developing MFi [2].
By the existence of MFi, it is expected that it may help the poor society, while at the same time keep the financial continuity, all of which are referred to as MFi Oath [3]. Dunford [4], stated that the balance between financial stability and social mission should be maintained as it is the main purpose of MFi. Outreach and continuity are two wholesome aspects. This view emphasized that the attempt to outreach poor society and keeping financial stability are inseparable, particularly the continuity to facilitate the outreach. Only by having excellent performance, the continuity of MFi programs to provide the access to the fund needed to prove the service for a huge amount of clients or poor society will be made possible [5].

Regarding the performance and continuity of MFi, some MFis manage to survive and succeed, while the others seem to be struggling. Those that are successful could maintain their financial sustainability due to their ability to adopt effective business practices. On the other hand, the unsuccessful MFi often fail because of bad business practices and mismanagement [6].

The bad performance in MFi is caused by (i) Bad financial management, (ii) the perception that credit is a grant. (ii) corruption, and (iv) lack of experience in every level of management [7]. Therefore, companies with higher risk require tight monitoring and supervising practices in order to have a better management system [8]. Because of that, MFis should pay attention to operational sustainability to provide optimum benefits for poor society in the long term. "Unsustainable MFi may help the poor society at the moment, yet it won't help them anymore in the future since it will disappear "[9]. 
This study is based on the belief that good corporate governance will result in effective decisions for the organization, MFi will be more transparent, accountable, responsible, and participatory. MFi with a reputation for good corporate governance will gain high trust and improve performance [10]. Management must ensure transparency in every aspect related to $\mathrm{MFi}$ operations and continuously improve user participatory skills [11]. The participation of members in teamwork activities, both in terms of quality and quantity, can increase the perception and control of members and can increase performance [12]. Moreover, participation is very much needed in community empowerment programs.

Based on the background above, it seems interesting to study the effect of corporate governance on the performance of MFi through the participation. Especially, the literature regarding the relationship of corporate governance on participation and performance is limited, whereas a study on the relationship between participation on social performance is none to be found at the moment.

\section{LITERATURE REVIEW AND HYPOTHESIS}

\section{A. Corporate Governance and Participation}

Management should ensure transparency in every aspect related to the operational of $\mathrm{MFi}$ and keep improving the participative skill of the user [11]. The improvement of participation would occur when the user as well as the investor are getting involved in making any decision and controlling the management of the organization democratically.

Participation is defined as the form of mental and emotional involvement in a group that encourages the person to contribute to achieving the goal of the group and share the burden and responsibilities during the process [12]. Participation from the members in teamwork activities, either from the quality or quantity aspect, could elevate both perception and control of the members and it could result in performance improvement [13].

Participation is required throughout the process of planning, execution, supervision, and capital provision. Attendance in the annual meeting has a positive effect on modal provision and encourages collective struggle to achieve the goal that would affect the performance of MFi [14]. Based on the theoretical and empirical studies conducted, hereby the hypothesis developed by the researcher:

H1. Corporate governance have a significant effect on participation

\section{B. Corporate Governance and Performance}

Corporate Governance is a mechanism, process, and relationship where a company is managed and directed [15]. Improving corporate governance practices leads to improving the accountability structure, minimizing the risk of fraud and misconduct by employees of the organization. Accountability, effective risk management, and internal control would reveal any potential problem before it turns into a huge crisis. Corporate Governance improves the management and supervision of the executives' performance [16].

Good corporate governance boosts the trust of investors and common society on MFi. Therefore, the Management selection process should be done carefully and thoroughly to select the right Management. The right, the strong and participative, Management is the most essential aspect to direct the MFi to reach their goal. Choosing the incorrect person could bring a serious risk for the MFi corporate governance [17]. Gohar and Batool [18], evaluated the effect of social and economic performance on the corporate governance of MFi in Pakistan. The findings presented that corporate governance affects the performance (economic and social) as well as the productivity of MFi. Based on the theoretical and empirical studies conducted, the researcher comes out with the following hypothesis:

H2. Corporate governance have a significant effect on financial performance

H3. Corporate governance have a significant effect on social performance

\section{Participation and Perfomance}

Participation contributes upon the management of the organization that is democratic, the better monitoring and the strength as well as the harmony of the internal urgency and the fulfillment of the expectation from the members [19]. Osterberg and Nilsson [20] mentioned that the participation, commitment, and loyalty of the members is an important issue, their trust upon the Management is affected by the economic background, age, and experience in cooperating.

In order to promote the progress or the growth of an organization, engagement is the most important factor. Through the participation of all things linked to the practice of action in the achievement of the objective. All projects that have to be carried out by the management must be assisted by all elements within the organization [21]. Meanwhile, Redjeki et al., [22] participation between the members has a significant effect upon the business performance. Participation from the members is very fundamental for the development of cooperation [23]. Based on the theoretical and empirical study, then the hypothesis developed as the following:

H4. Participation has a significant effect on financial performance

H5. Participation has a significant effect on social performance

\section{Financial Performace and Social Performance}

Dunford [4], mentioned the necessity of keeping the balance between the financial continuity and the social mission is the main goal from MFi. The outreach and the continuity in the micro-financial are two sides of the entirety. This perspective emphasized that reaching the poor people and the 
continuity is completing each other, especially the continuity in providing the outreach. Only with high performance that the continuity of the micro financial program gained access upon the needed funding to serve a big number of the clients that are the poor people [5]. The continuity of the MFi will give a longterm service to the poor people [24-26]. Several kinds of research indicated that financial performance has a positive effect on social performance [27,28]. The hypothesis is established as follows, based on theoretical and empirical study:

H6. Does financial performance have a significant effect on social performance

Based upon the above description, the hypothesis of the influence between variables which is formulated in 6 hypotheses can be seen in the hypothetical framework Figure 1.

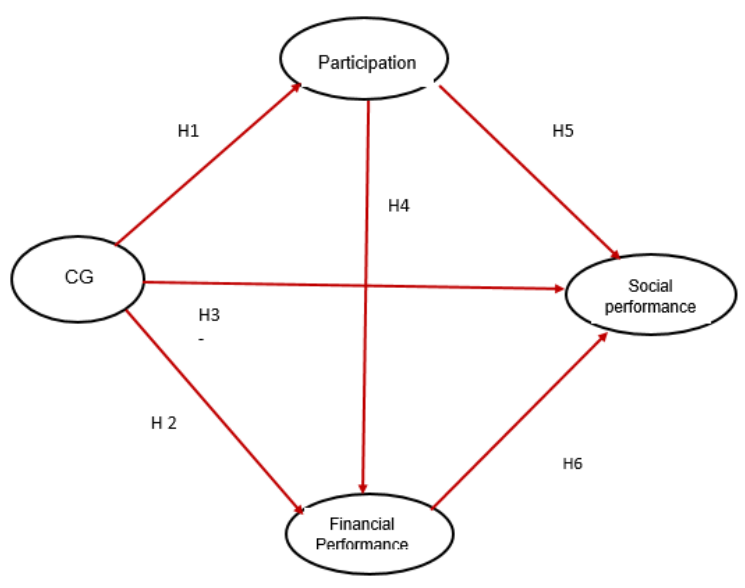

Fig. 1. Hypothetical framework.

\section{RESEARCH METHODS}

\section{A. Data Collection and Sample}

The study population contains a total of 134 MFIs of the Community Empowerment Program located in rural areas of the Southern Kalimantan Province, with the parameters of:

- Consecutively, from 2014 to 2018 doing the annual meeting.

- The MFi reported the statement of financial position and the report of the income statement consecutively from 2014 to 2018 .

- The age of the MFi is above 10 years.

Based on the three criteria, the ones fulfilling the requirement of population for the research are 75 MFis. The sampling technique used is the saturated sampling for the ones fulfilling the criteria for the research sampling. The research uses the data panel that is a mixture between the data of time series and the cross section. The data panel consists of 75 MFis $x 5$ years, so that the data is in the total of 375 .

\section{B. Measurement}

TABLE I. VARIABLES, INDICATORS, MEASUREMENT AND SOURCES

\begin{tabular}{|c|c|c|c|}
\hline Variable & Indicator & Measurement & Source \\
\hline \multirow{4}{*}{$\begin{array}{l}(\mathrm{X} 1) \\
\text { Corporate } \\
\text { Governanc } \\
e\end{array}$} & (X1) Board Size & $\begin{array}{l}\text { Number of board } \\
\text { members }\end{array}$ & [29] \\
\hline & $\begin{array}{l}\text { (X2) Diversity } \\
\text { Board }\end{array}$ & $\begin{array}{l}\text { Percentage of total } \\
\text { female board members }\end{array}$ & [29] \\
\hline & $\begin{array}{ll}\text { (X3) } & \text { Board } \\
\text { Meeting } & \\
\end{array}$ & $\begin{array}{l}\text { The frequency of board } \\
\text { meetings in a year }\end{array}$ & {$[30]$} \\
\hline & $\begin{array}{l}\text { (X4) } \\
\text { Independent } \\
\text { Board } \\
\end{array}$ & $\begin{array}{l}\text { Percentage of number of } \\
\text { board members outside } \\
\text { of users }\end{array}$ & {$[30]$} \\
\hline \multirow{2}{*}{$\begin{array}{l}(\mathrm{Y} 2) \\
\text { Partici } \\
\text { Pation }\end{array}$} & $\begin{array}{l}(\mathrm{Y} 2.1 .) \% \text { Of } \\
\text { users present in } \\
\text { annual meeting }\end{array}$ & $\begin{array}{l}\text { Percentage of MFI users } \\
\text { who attend annual } \\
\text { meeting }\end{array}$ & [31] \\
\hline & $\begin{array}{l}\text { (Y2.2.)\% Users } \\
\text { who in board }\end{array}$ & $\begin{array}{l}\text { Percentage of Mfi users } \\
\text { in the Board }\end{array}$ & [31] \\
\hline $\begin{array}{l}\text { ( Y3) } \\
\text { MFI } \\
\text { perfor } \\
\text { mance }\end{array}$ & (Y3.1) ROA & $\begin{array}{l}\text { Return on assets is net } \\
\text { income divided by total } \\
\text { assets }\end{array}$ & {$[32]$} \\
\hline \multirow{5}{*}{$\begin{array}{l}\text { X4 } \\
\text { Social } \\
\text { perfor } \\
\text { mance }\end{array}$} & $\begin{array}{l}(\mathrm{Y} 3.2) \\
\text { OSS }\end{array}$ & $\begin{array}{ll}\text { Operational self- } \\
\text { sufficiency is total } \\
\text { income divided by total } \\
\text { expenses }\end{array}$ & {$[32]$} \\
\hline & $\begin{array}{l}(\mathrm{Y} 3.3) \\
\text { FSS }\end{array}$ & $\begin{array}{l}\text { Financial self- } \\
\text { sufficiency is the ratio } \\
\text { between income to total } \\
\text { expenditure }+5 \% \text { of the } \\
\text { total loan }\end{array}$ & {$[32]$} \\
\hline & $\begin{array}{l}\text { (Y3.4) } \\
\text { Number } \\
\text { active } \\
\text { borrowers }\end{array}$ & $\begin{array}{l}\text { Number of active } \\
\text { borrowers }\end{array}$ & {$[33]$} \\
\hline & $\begin{array}{l}\text { (Y3. 5) Average } \\
\text { Loan }\end{array}$ & $\begin{array}{l}\text { Total funds borrowed / } \\
\text { total borrowers }\end{array}$ & {$[33]$} \\
\hline & $\begin{array}{l}\text { (Y3.6) } \\
\text { Number of } \\
\text { female } \\
\text { borrowers }\end{array}$ & $\begin{array}{l}\text { The ratio of female } \\
\text { borrowers to the total } \\
\text { number of borrowers }\end{array}$ & {$[33]$} \\
\hline
\end{tabular}

Source: Previous Research (2020)

\section{Data Analysis}

The analysis data used inferential statistical analysis is used to test the effect of the variables in this research. The researcher used the WarpPLS statistical tool [34].

\section{RESEARCH FINDINGS}

\section{A. Hypothesis Test}

By comparing the $\mathrm{p}$ value with alpha 5 percent, based on the results of hypothesis testing. If the $p$ value is 0.05 , then the hypothesis is accepted and the hypothesis is rejected if the $p$ value is $>0.05$. The resulting test results for the hypothesis are as follows Table 2 . 
TABLE II. HYPOTHESIS TESTING RESULTS

\begin{tabular}{|l|l|l|l|l|}
\hline $\begin{array}{c}\text { Hypo } \\
\text { thesis }\end{array}$ & $\begin{array}{l}\text { Influence between } \\
\text { variables. }\end{array}$ & $\begin{array}{c}\text { path } \\
\text { coefficient }\end{array}$ & P Value & $\begin{array}{c}\text { Sign } \\
\text { level }\end{array}$ \\
\hline 1 & $\begin{array}{l}\text { CG towards } \\
\text { Participation }\end{array}$ & 0.794 & $<.0 .001 *$ & Significant \\
\hline 2 & $\begin{array}{l}\text { CG on financial } \\
\text { performance }\end{array}$ & -0.147 & $<0.001 *$ & Significant \\
\hline 3 & $\begin{array}{l}\text { CG on social } \\
\text { performance }\end{array}$ & -0.173 & $<0.001 *$ & Significant \\
\hline 4 & $\begin{array}{l}\text { Participation on } \\
\text { financial performance }\end{array}$ & -0.178 & $<0.001 *$ & Significant \\
\hline 5 & $\begin{array}{l}\text { Participation on social } \\
\text { Performance }\end{array}$ & -0.704 & $<0.001 *$ & significant \\
\hline 6 & $\begin{array}{l}\text { Financial performance } \\
\text { on social Performance }\end{array}$ & 0.091 & $0.037 *$ & Significant \\
\hline
\end{tabular}

Source: Secondary data processed, 2020

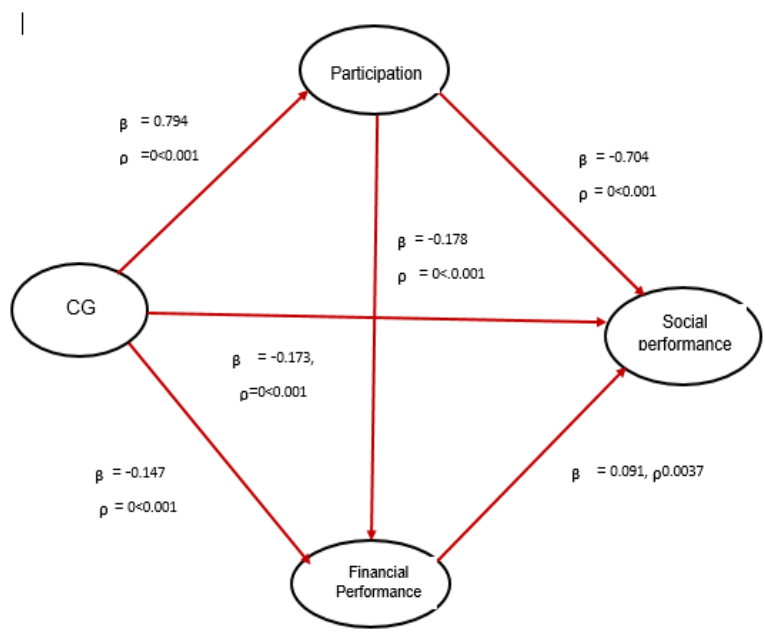

Fig. 2. Final structural model.

\section{DISCUSSION}

The outcome of the study showed that corporate governance has an important influence on participation. The results showed that the greater the degree of intervention, the better corporate governance is. Supported study results [35], that indicated that there is a significant relationship between corporate governance with the participation. The result of the research also supported the Signaling Theory [36] that indicated that good corporate governance is a good signal for all the users/members to participate in the MFi.

The findings indicated that corporate governance has a big negative affect on financial and social results. Many factors that can have a substantial negative impact on the output of MFIs are: First, most (54.5\%) of being Board of MFi are sided jobs and dedication. Second, most of the Board of Mfi were women (64.15\%). The negative relationship between Board diversity and technical efficiency can also be explained by the theory of tokenism [37]. "Token" refers to a person who meets formal requirements but does not have the additional characteristics required for a particular job or position.
The findings of this study support Thrikawala et al [29] that more and more female directors are having a major negative impact on results. The explanation for women's negative impact is that women are inferior to men in a male-dominant society and are therefore silent and inactive. The effect is a marginal impact on the financial performance of the MFI. The findings also support Ferial et al [38] that good corporate governance has had a significant negative impact on financial.

The findings also support Gohar [18] that the success (economic and social) and productivity of MFIs in Pakistan is affected by corporate governance. Larger management is inversely associated with economic growth. A negative contributor to performance, outreach, and productivity is the duality of the chair with the CEO.

Participation has a significant adverse impact on economic and social results. Based on the Amini [39] findings, indicated that participation depends on age, education, and investment level. The participation has a negative effect upon the performance is possible because of the low participation in the annual meeting $(26.17 \%)$ and only $16 \%$ of the users that are on the board. The other cause is possible due to the present members in the annual meeting is the users with lower levels of education and is from the poor group of people, so that their presence in the annual meeting has not contributed adequately due to its limitation.

The final finding is that financial performance has a significant positive relationship upon social performance. This finding supported the perspective that emphasizes that to approach poor people and maintain continuity is fulfilling each other, and especially in providing the outreach. Only with having a good financial performance, the continuity of the micro financial program can gain access to the funding that is needed to serve a big amount of clients of poor people [5]. Several kinds of research indicated a positive relationship between the financial and social performance [27,28].

\section{CONCLUSION}

The MFi program of community empowerment in Indonesia has been proven to give ease of access for the financial service for the people that so far are not served by the financial existing institution. The result of the research indicated that a good social performance will be achieved if it is supported by the continuous financial performance and with the support of corporate governance as well as the support of the participation from the users.

The result of the research indicated that corporate governance has a significant positive effect upon participation, corporate governance has a significant negative effect upon the financial and social performance, and meanwhile, other findings indicated that there is a significant negative effect on the participation of the financial and social performance. The last finding of the research is that financial performance has a significant positive effect upon social performance, this shows that there is no trade-off between financial sustainability and the social mission of MFi. 
The limitation of the research is that this research is done using the quantitative approach so that to have more focus on the study of quality for the corporate governance and the participation level in the MFi needs to be studied qualitatively.

\section{REFERENCES}

[1] Bappenas, Evaluasi PNPM Mandiri, Direktorat Evaluasi Kinerja Pembangunan Sektoral. Kementerian PPN /(BAPPENAS), 2013.

[2] Pedoman Umum Proyek Pemberdayaan Masyarakat Untuk Pembenagunan Desa /PMPD (Community Empowerment for Rura Development / CERD ), Dirjen Pemberdayaan Masyarakat dan Desa. Departemen Dalam Negeri Republik Indonesia, 2003.

[3] J. Morduch, "The Microfinance Promise," Journal of Economic Literature,vol. 37, no. 4, pp. 1569-1614, 1999.

[4] C. Dunford, Evidence of MFi's Contribution to Achieving The Millennium Development Goals Paper for The Global Microcredit Summit, Halifax, Nova Scotia, Canada. 14pp. on Freedom from Hunger Self Help for Hungry world, 2006.

[5] E. Rhyne, The Yin and Yang of MFi: Reaching The Poor and Sustainability, Microbanking Bulletin July, 1998.

[6] N.L. Zuru, K.H. Mohd and A. Darwina, Business Practices for Sustaining Performance of MFi Institutions: A Literature Review. International Journal of Management Research \& Review. Vol. 6, no. 8, pp.1000-1011, 2016

[7] D. Holloh, Review Of The PPK Microcredit Approach: World Bank Group, Washington DC, 2001.

[8] B.S. Black, H. Jang and W. Kim, "Does Corporate Governance Predict Firms' Values? Evidence From Korea," Journal of Law , Economic and Organization, vol. 27, no. 2, pp. 366-413, 2006.

[9] M. Schreiner, "Ways Donors Can Help The Evolution of Sustainable MFi Organizations," Savings and Development, vol. 24, no. 4, pp. 423 437, 2000.

[10] D. Augustine, "Good Practice in Corporate Governance: Transparency, Trust, and Performance in The MFi Industry," Business \& Society, vol. 51, no. 4, pp. 659-676, 2012

[11] R. Shaffer, S. Deller and D. Marcouiller, "Rethinking Community Economic Development," Economic Development Quarterly, vol. 20, no. 1 , pp. $59-74,2006$

[12] K. Davis and J. Newstrom, Human Behavior at Work. Organization Behavior 8th Edition. Singapore: Mc. Graw-Hill. International, 1989.

[13] A. Rajesh, K.V. Raju, P. Reddy, R. Shrinivasan and M.S. Sriram, "Member-funds and Cooperative Performance?," IIMA Working Papers WP2002-10-01, Indian Institute of Management Ahmedabad, Research and Publication Department, 2002

[14] A. Othman, F. Kari, R. Jani and R. Hamdan, "Factors Influencing Cooperative Membership and Share Increment: An Application of the Logistic Regression Analysis in the Malaysian Cooperatives," World Review Of Business Research, vol. 2, no. 5, pp. 24-35, 2012.

[15] E. Rhyne, Quality Financial Services for All. Funding Development. Global Development Goals, pp.47-49. UNA-UK, 2014.

[16] IFC, The Indonesia Corporate Governance Manual, First Edition, IFC and OJK, 2014

[17] F.M. BBVA, Universal Corporate Governance Code For MFi Institution 1st ed., Madrid: Fundación Microfinanzas BBVA, 2011.

[18] R. Gohar and A. Batool, Effect of Corporate Governance on Performance of MFi Institutions: A case from Pakistan, Emerging Market Finance and Trade, 51: sup6,S94-S106, 2015.

[19] Banco Central Do Brasil, Cooperative Governance: Guidelines for Good Practices of Financial Cooperative Governance. Brasilia, 2008.
[20] P. Osterberg and J. Nilsson, Members' Perception of Their Participation in The Governance of Cooperatives: The Key to Trust and Commitment in The Agricultural, 2009.

[21] S.N. Faidah and R.M. Dewi, Penerapan sistem Tanggung Renteng Sebagai Upaya Mewujudkan Partisipasi Aktif Anggota Dan Perkembangan Usaha di Koperasi Perempuan Setia Bhakti Jawa Timur. Jurnal online Universitas Negeri Surabaya, 2, 2013.

[22] A.M. Redjeki, B. Purwoko and A.M. Sumarlin, Analisis Strategi Fungsional Tentang Pengaruh Komitmen Dan Partisipasi Anggota Terhadap Kinerja Koperasi Pemerintah (Studi Kasus Koperasi Pegawai Kementerian Sosial RI). Jurnal online Pascasarjana Universitas Pancasila. Jakarta, 2016.

[23] Y.M. Aini, H.A.K. Hafizah and Y. Zuraini, "Factors Affecting Cooperatives" Performance in Relation to Strategic Planning and Members' Participation,' Procedia-Social and Behavioral Sciences, 65, 100-105, 2012.

[24] G.D. Nyamsogoro, Financial Sustainability of Rural MFi in Tanzania $\mathrm{PhD}$ thesis, University of Greenwich, Greenwich, 2010.

[25] J.C. Brau and G.M. Woller, MFi: A Comprehensive Review of Existing Literature, Journal of Entrepreneurial Finance and Finance Ventures, 9 (1), pp. 1-26.

[26] G. Woller, C. Dunford and W. Warner, Where to MFi, International Journal of Economic Development, vol. 1, no. 1, pp. 29-64, 1999.

[27] K. Gakhar and M. Meetu, "Social and financial performance of microfinance indtitutions: Is there a trade-off?," Avesha, vol. 9, no. 1, pp. $36-44,2016$

[28] P. Kaur, "Efficiency of microfinance institutions in India : Are they reaching the poorest of the poor?," Vision, vol. 20, no. 1, pp. 54-65, 2016

[29] S. Thrikawala, S. Locke and K. Reddy, "Board Structure -Performance Relationship in MFi Institution (Mfi) in An Emerging Economy," Corporate Governance: The International Journal of Business in Society, vol. 16, no. 5, pp.815-830, 2016

[30] K. Ahmed and R. Khan, Disclosure Practices and Governance Quality : Evidence From Micro Finance Institutions, Journal of Accounting \& Organizational Change, vol. 12, no.3, pp.325-350, 2016

[31] D.M. Pozzobon and Z. Decio, "Member Participation in Cooperative Governance: Does Heterogeneity Matter? Encontro da ANPAD XXXV," Rio de Janeiro, September, 2011

[32] N.W. Marwa and M.J. Aziakpono, "Financial Sustainability of Tanzanian Saving and Credit Cooperatives," International Journal of Social Economics, vol. 42, vol. 10, pp. 870-887, 2015.

[33] A. Bakker, S. Jaap and N. André, "Governance and MFi Institutions," Corporate Governance, vol. 14, no. 5, pp. 637 - 652, 2014.

[34] F. Solimun and A.A.R. Nurjannah, Metode Statistika Multivariat Pemodelan Persamaan Struktural (SEM) Pendekatan WarpPLS, UB Press.Malang

[35] F. Ernita and A. Al-Rozi, "Factors Affecting The Members Participation On Cooperative In North Sumatera," International Journal Of Scientific \& Technology Research, vol. 3, no. 10.

[36] M. Spence, "Job Market Signaling", The Quarterly Journal of Economics, vol. 87, no. 3, pp. 355-374, 1973.

[37] R.M. Kanter, Man and women of the corporation. New York: Basic Book, 1997.

[38] F. Ferial, S.R. Suhadak and Handayani, "Pengaruh Good Corporate Governance terhadap Kinerja Keuangan dan Efeknya terhadap Nilai Perusahaan (studi pada badan Usaha Milik Negara yang terdaftar di Bursa Efek Indonesia periode 2012-2014)," Jurnal Administrasi Bisnis, vol. 33, no. 1, 2016

[39] A.M. Amini and M. Ramezani, "Investigating The Success Factors of Poultry Growers' Cooperatives in Iran's Western Provinces," World Applied Sci. J, 5, 81-87, 2008 